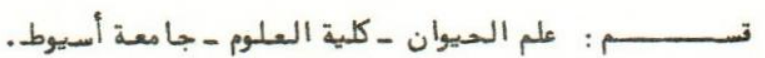

$$
\begin{aligned}
& \text { رئيس القسم: أ .د / محمد خليل النغــار. }
\end{aligned}
$$

$$
\text { د راسات على بعف الصفات المرستيكية لسمكتى الستس نيرس }
$$

$$
\text { عبد الحميد خليل ، عزت جرجس يوافيم ، امام عبد الغنى مكاوى }
$$

يتضمن هذا البحث د راسات على بعض الصفات المرستيكية لسمكتى الستس نسيرس والستس باريموز

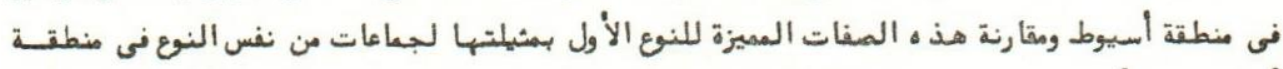

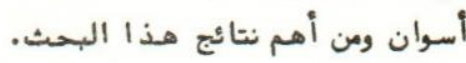

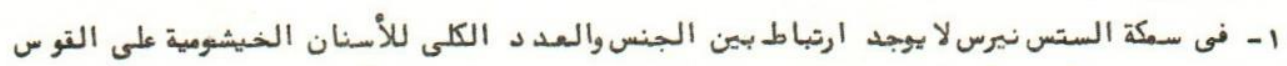

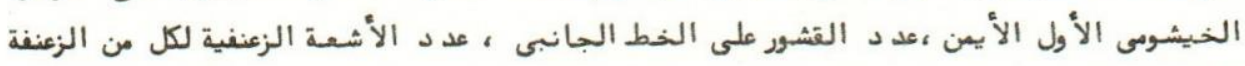

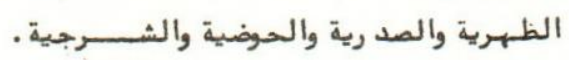

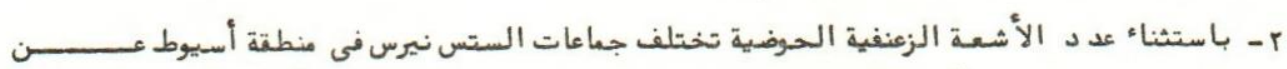

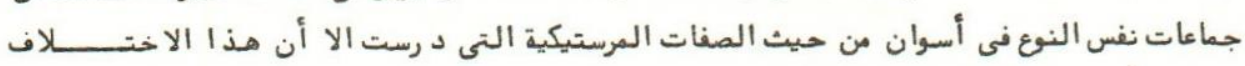

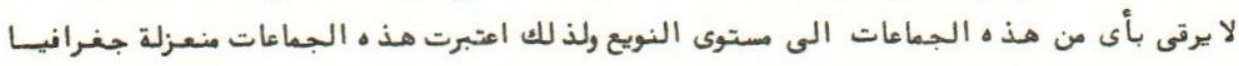

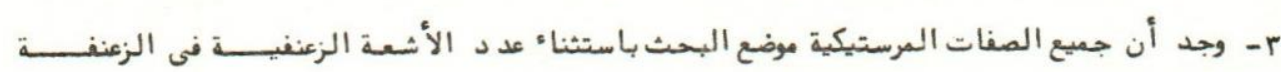

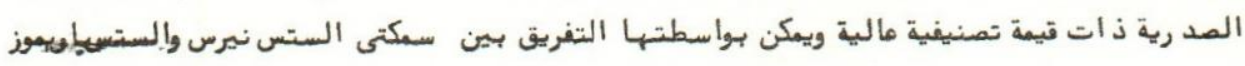

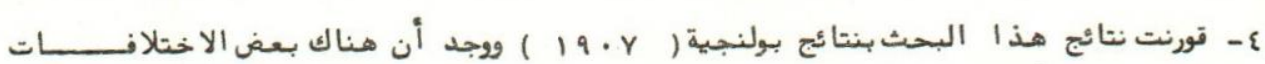

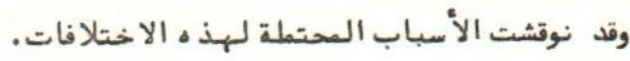



Dept. of Zoology,

Faculty of Seience, Assiut University,

Head of Dept. Prof. Dr. M.K. El-Naffar.

\section{STUDIES ON CERTAIN MERISTIC CHARACTERS OF TWO NILE CHARCOID FISHES ALESTES NURSE AND ALESTES BAREMOSE \\ (With 24 Tables)}

By

A. KHALIL: E, J. YOAKIM and I,A. MEKKAWY

(Received at 25/5/1982)

SUMMARY

In each of Assiut and Aswan samples of Alestes nurse, counts of the total gill rakers on the first right side gill arch, lateral line scales and fin rays of dorsal, pectoral pelvic and anal fins were not assoclated with sex. The results of meristic counts, except those of pelvic fin rays, revealed that Assiut and Aswan combined sex samples of A.nurse represented geographical races and not a subspecific status. Except for the dorsal fin ray count, the meristic counts considered were found to be helpful for the differentiation between $\underline{A}$. nurse and $\underline{A}$.baremose.

\section{INTRODUCTION}

Studies on the meristics of some fishes attracted the attention of many investigators including MAITA (1953), LAGLER et al, (1962), DU PLESSIS (1963), BOTROS et al. (1970), LACHNER and JENKINS (1971), BISHARA (1973) and QADRI (1974). GERY (1977) extensively reviewed the literature concerning the systematics of the African charcoid fishes, many of which were based on meristic studies. He mentioned some difficulties concerning the systematies of charcoids in general and Nile Alestes species in particular; many of such species are sibllngs, being differentiated only by minor characteristics. The present investigation gives an account on certain meristics of the Nile charcoid fishes, Alestes nurse and Alestes baremose.

\section{MATERIAL and METHODS}

The present study is based on the examination of random samples of Alestes nurse and Alestes baremose which were collected from the commercial catch from Assiut fish markets during the period May 1977-June 1979; also random samples of A.nurse were collected from Aswan fish markets during July and August 1978. Table (1) shows the number and total length range of the fishes examined for the meristic characters considered in the present investigation. Due to the rarity of $\underline{A}$. baremose specimens during the period of collection, such specimens were investigated without consederation of sex.

Gill rakers on the external side of the first right side gill arch were counted. Also, the number of gill rakers on the external side of the horizontal and ascending branches of that gill arch was recorded.

The numbers of soft rays of the dorsal, pectoral, pelvic and anal fins were recorded. The last two closely set rays of both dorsal and anal pins were recorded as one.

The predorsal scales anterior to the dorsal fin, scales around the body (one scale anterior to the dorsal fin), scales around the caudal peduncel at its narrowest point and lateral line scales on the left side were counted. When some scales were lost, their pockets were counted.

The data of the meristic characters considered in the present investigation were subjected to analyses of variance and covariance and Chi-square test according to SIMPSON et al. (1960). The coefficient of difference (C.D.) for the meristic characters considered of Assiut and Aswan populations of $\underline{A}$.nurse was calculated as prescribed by MAYR et al. (1953). According to them, C.D. values equal to 1.28 and higher are considered indicative of subsepecific status. At that value, $90 \%$ of the fish in each of the two populations being compared differ from one another. 
A. KHALIL, et al.

\section{RESULTS}

\section{Alestes nurse}

\section{C111 Raker Counts}

The ranges, means and percentages of occurrence of total gill raker counts on the first right side gill arch of Assiut and Aswan male, female and combined sex samples are shown in Tables 2-5. The variation of the total gill raker counts of Assiut and Aswan combined sex samples according to the fish size is presented in Table 6. Such variation was found ta be curvilinear (Table 7).

The total gill raker counts were not assoclated with sex in each of Assiut and Aswan samples (d.f.= 11; $X^{2}=15.855 ; P=0.20-0.10$ and $d . f .=9 ; X^{2}=3.937 ; p=0.98-0.90$ respectively). A highly significant difference (d. $\left.f .=11 ; X^{2}=82.997 ; P \perp 0.001\right)$ was found between the total gill raker counts of Asslut and Aswan combined sex samples. These results suggest the presence of isolated populations of A.nurse in Assiut and Aswan localities.

The percentage of occurrence of gill raker counts on the horizontal and ascending branches of the first right side gill arch of Assiut and Aswan combined sex samples is presented in Table 8 . In such samples, the range of gill raker counts on those branches of the first right side gill arch varied according to the total gill raker count of that arch (Table 9).

The mean values of gill raker counts on the horizontal branch of the first right side gill arch of Assiut and Aswan combined sex samples revealed a highly significant difference ( $F=51.11$; d.f. $=1,189 ; 1 \underline{10} 0.01) . B y$ contrast, the mean values of such counts on the ascending branch of that gill arch of those samples were insignificantly different $\left(F=0.24\right.$; d.f. $\left.=1,189 ; P^{0} 0.05\right)$. Accordingly, the variation of the total gill raker counts of Assiut and Aswan combined sex samples was mainly due to the variation of the number of gill rakers on the horizontal branch; variation of the number of gill rakers on the ascending branch did not contribute, whatsoever, In this respect.

Scale Counts

The ranges, means and percentages of occurrence of lateral line scale counts of Assiut and Aswan male, female and combined sex samples are shown in Tables 2,3,10 and 11 . The ranges, means and percentages of occurrence of counts of predorsal scales, scales around the body and scales around the caudal peduncel of Assiut combined sex samples are presented in Tables 12 and 13.

In each of Asslut and Aswan samples, the lateral line scale counts were not associated with sex (d.f. = 7; $X^{2}=9.385 ; P=0.30-0.20$ and $d . f .=8 ; X^{2}=11.381 ; P=0.20-0.10$ respectively). A highly significant difference (d.f.= 9; $\left.X^{2}=418.334 ; P / 0.001\right)$ was found between those counts of Assiut and Aswan combined sex samples. These results are tempting to subgest that Assiut and Aswan samples represented isolated populations.

Fin Ray Counts

The ranges means and percentages of occurrence of the dorsal, pectoral, pelvic and anal fin ray counts of Assiut and Aswan male, femal and combined sex samples are given in Tables 2,3,14,15,16 and 17.

In each of Assiut and Aswan samples, there was no association between sex and the dorsal, pectoral, pelvic and anal $f$ in ray counts (For Assiut samples: d.f. $=2, x^{2}=1.94, P=0.50-0.30 ;$ d.f. $=5, x^{2}=0.25, P>^{0.98}$; d.f. $=3$, $X^{2}=2.67, P=0.50-0.30 ;$ d. $f .=4, X^{2}=1.48, P=0.90-0.80$ respectively. For Aswan samples: d. $P .=1, X^{2}=2.25, P=0.20-$ 0.10 ; d.f. $=4, x^{2}=0.76, P=0.98-0.90 ;$ d.f. $=2, x^{2}=0.92, P=0.70-0.50 ;$ d.f. $=4, x^{2}=3.97 ; P=0.50-0.30$ respectively). But for the pelvic fin ray count (d.f. $=3, x^{2}=4.69, P=0.20-0.10$ ), the fin ray counts of Assiut combined sex samples were highly significantly different from those of Aswan ones (d.f. $=2, x^{2}=19.65, \mu / 0.001 ;$ d.f. $=5$, $x^{2}=91.48, P / 0.001 ; d . f .=5, x^{2}=63.64, P / 0.001$ for dorsal, pectoral and anal fin ray counts respectively). These results suggest that Assiut and Aswan samples represented isolated populations.

\section{Alestes baremose}

Table 12 and Tables 18-22 summarize the ranges, means and percentages of occurrence of counts of the lateral line scales, predersal sclaes, scales around the body, scales around the caudal peduncle, total gill 
CERTAIN MERISTICS OF THO NILE CHARCOID FISHES

rakers on the first right side gill arch, dorsal fin rays,pectoral fin rays, pelvic fin rays and anal fin rays.

DISCUSSION

There has been much debate concerning the reasons and interpretations of meristic variations in fishes. SCHMIDT (1930) mentioned that there are sensetive periods of development during which vertebral and $\rho$ in ray counts are influenced by the environment. He came to the conclusion that the sensetive period of the number of fin rays occurs somewhat later than that governing vertebral count. LAGLER et al. (1962) reported that the rate of embryonic development has something to do with meristic elements such as vertebrae, rays of median fins and number of scale rows. QUAST (1964)was of the opinion that variations in the process of body segmentation during early ontogeny are probably the basic source of variation in meristics associated with body somites.

The temperature of water at the early developmental stages of some fish was found to affect their meristics. HUBBS (1926) suggested that increased meristic counts in fish representatives of northern hemisphere can be cuased by dissimilar effects of low temperature on the embryonic rates of growth and differentiation. He theorized that both rates are slowed by low temperatures, but differentiation is slowed more than growth with the result that the embryo is larger at the time that differentiation of meristic elements takes place. One may conclude that a large number of meristic elements results in organs of such an embryo, because of the greater amount of actual tissue space available when the meristic elements are formed. Such conclusion is in accord with the results arrived at by HUBBS and HUBBS (1945) who mentioned that meristic elements such as vertebrae, scales and fin rays are laid down at a relatively constant distance apart in absolute terms, and that the number of elements depends on the space available up to the time when development stops. LAGLER et al. (1962) found that Notemigonus crysoleucas, a North American minnow, has more meristic elements in the north than it does at the southern extent of its range near the Gulp of Mexico. They suggested that less energy is spent in general metabolism in northern latitudes where development proceeds at low temperature than in southern latitudes. Thus, in the north more of the nutritive material of the egg is made available for synthesis of meristic elements than in the south. BISHARA (1973) reported that the effect of temperature may explain the considerable wide range in the number of $f$ in rays of Tilapia species in some Egyptian lakes. According to her, those fish species have extended spawning period which amounts to about 9 months, so some populations develop their early stages in the highest temperature of summer months, while others develop their early stages in a comparatively lower temperature during spring and autumn.

Many investigators tried to assess the relative contributions of genetic or environmental influences on meristic varlations. HUBBS (1926)indicated that environmentally related clinal variation in meristic characters may reflect some degree of genetic differences. CORDON (1957) considered that many of the meristic traits that distinguish geographic races of fish are inherited, but that environmentally related clinal varlation in meristic characters may reflect some degree of genetic differences. GORDON (1957) considered that many of the meristic traits that distinguish geographic races of $f i s h$ are inherited, but that environmental conditions strongly influence the final expression. He considered that the variability of such traits may be due to genetic drift. BARLOW (1961) believed that regular changes in meristic counts such as occur in geographic clines may reflect adaptive changes of genetic nature and he reviewed evidence that there is sometimes a selective advantage in a species having a given number of meristic elements in a given environmental situation. Thus one may conclude that meristic variations of geographical races or isolates are based partly upon environmental modifications, the extent of which is partially controlled by the genotype in an adaptive manner.

In Assiut and Aswan combined sex samples of A.nurse, a curvilinear relationship between the number of gill rakers and fish length was revealed. BOTROS et al. (1970) reproted that the number of gill rakers of both Sardinella maderensis and Sardinella aurita collected from Alexandria Increased with increase of fish length. Linear and curvilinear relationships between gill raker count and the length of certain Iilapia species of lake Manzalan were reported by BISHARA (1973).

Assiut Vet. Med.J.Vol. 11, No. 21, 1983. 


\section{A. KHALIL, et al.}

In the present investigation, it was possible to differnetiate between Assiut and Aswan samples of A. nurse on the basis of gill raker counts of the first right side gill arch or its horizontal branch. MATTA(1953) considered the gill raker counts on the first'right side gill arch of Merluccius merluccius to be of systematic value. EZZAT et al. (1976) compared the gill raker counts of the horizontal and ascending branches of the first right side gill arch of Merluccius merluccius with those reported by different authors and they concluded that gill raker counts were helpful to differentiate between different populations of the aforementioned species from different localities.

The meristics considered in the present investigation for $\underline{A}$.nurse were not associated with sex in each of Assiut and Aswan samples. DURAND and LOUBENS (1972) found insignificant differences between sexes for anal ray counts of Alestes baremose. PAGE and BRAASCH (1976) stated that males of Etheostoma smithi had more dorsal fin rays than Pemales.

The results of meristic counts considered in the present investigation, except those of pelvic fin.rays, revealed that Assiut and Aswan combined sex samples of A.nurse represented 1solated populations. However, the coefficient of difference (C.D.) between such counts of those samples did not attain the value of 1.28. Accordingly, samples of $A$.nurse from those localities did not represent a subspecific status; they could be only considered as geographical races or isolates.

Except for the dorsal fin ray count, the meristic characters considered in the present investigation were found to be helpful for the differentiation between $\underline{A}$.nurse and $\underline{A}$. baremose. By using some meristic characters, DU PLESSIS (1963), LACHNER aAd JENKINS (1971) and BISHARA (1973) were able to differentiate between Labeo species in the Transvaal, species of Necomis biquttatus group in the Arkansas River drainage and I1lapia species in lake Manzalah respectively. QADRI (1974) was able to clarify the status of Salvelinus marstoni, Salve11nus oquassa and Salvelinus aureolus in edstern North America by minor differences in some of their meristic characters. He concluded that the three forms are conspecific and should be synonymized as Salvelinus alpinus oquassa.

A comparison between the meristic characters of $A$.nurse and $\underline{A} \cdot$ baremose considered in the present investigation with those reproted by BOULENGER (1907) revelaed some variations (Tables 23 and 24). Such variations may be due to the rarity of specimens examined by Boulenger, variations of environmental factors prevailing nowadays in the Nile as compared with those at the time of Boulenger, adaptive changes of genetic nature or all these factors.

\section{REFERENCES}

Barlow, G.W. (1961): Syst. Zool., 10 (3): 105-117.

Bishara, N.F. (1973): Ph.D. dissertation, Cairo University.

Botros, G.A.; El-Maghraby, A.M. \& Soliman, A.M. (1970): Bull. Inst. Ocean. Fish., 1: 83-128.

Boulenger, G.A. (1907): Zoology of Egypt. The Fishes of the Nile. London, Hugh Rees Ltd.

Du Plessis, S.S. (1963): Annals of the Transvaal Meuseum, 24 (4): 327-337.

Durand, J.R. \& Loubens, G. (1972): Rech. Sci. Tech. Outre. Mer. Ser. Hydrobiol., 5 (2): 113-136.

Ezzat, A.A.; Ramadan, A.L. \& Hafez, S. (1976): Revue des Travaus de l'Institut des Pêches Maritimes TXL Fasc.

3 et $4: 566-587$.

Gery, J. (1977): Charcoids of the World. Neptune City: T.F.H. Publications, Inc.

Gordon, M. (1957): Physiological gentics of fishes. In Brown, M.E. (ed), The Physiology of Fishes, Vol. 2, pp.

431-501. London, Academic Press.

Hubbs, C.L. (1926): Amer. Nat., 60: 57-81.

Hubbs, C.L. and Hubbs, L.C. (1945): Papers of the Michigan Academy of Science, Arts and Letters, $30: 1-310$.

Lachner, E.A. and Jenkins, R.E. (1971): Smithsonian Contributions of Zoology, 91: 1-28.

Lagler, K.F.; Bardach, J.E. \& Miller, R.R. (1962): Ichthyology. New York, Wiley.

Matta, F. (1953): Note I. Boll. Pesca, Piscicol. e Idrobiol., Rome, 8 NS (1): 82-102. 
Mays, E; Linsley, E.G. \& Usinger, R.L. (1953): Methods and Princliples of Systenatic Zoology. New York, McGrawHill.

Page, L.M. \& Braasch, M.E. (1976): Occasional Papers of the Museum of Natural History, the University of Kansas, Lawrence, Kansas, 60: 1-18.

Qadri, S.U. (1974): J. Fish. Res. Board Can., 31: 1355-1361.

Quast, C. (1964): Fish. Bull. U.S. Dept. Int. Fish and Wildl. Serv., 63 (3): 589-610.

Schmidt, J. (1930): C.R. Trav. Lab. Carlsberg, 18 (6): 153-155.

Simpson, G.G.; Roe, A. \& Lewontin, R.C. (1960): Quantitative Zoology. New York, Harcourt, Brace and World, Inc.

Table 1: The number and tatel length range of the fishes examined for certain meristic characters of d. nurse and ئ. baremobe.

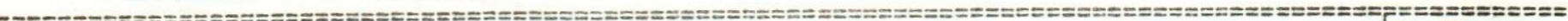

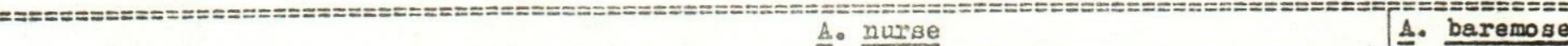

Items of study

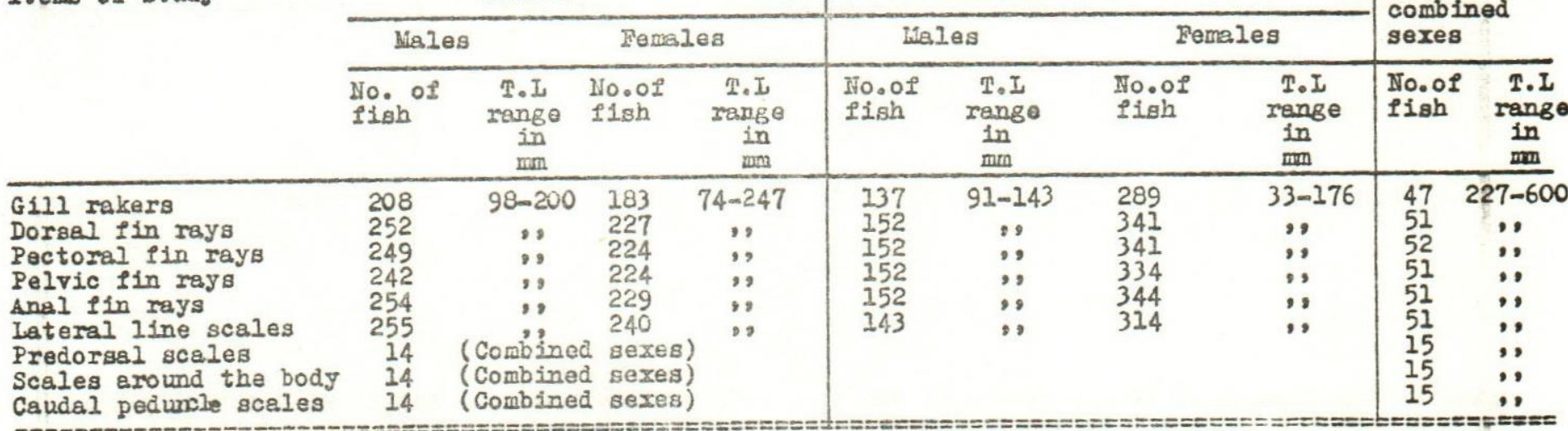

Table 2: The ranges and meang of different mexistic cheracters of A. nurse (males and females) off Assiut and Aswan.

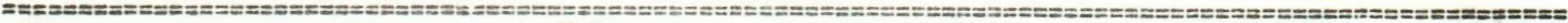

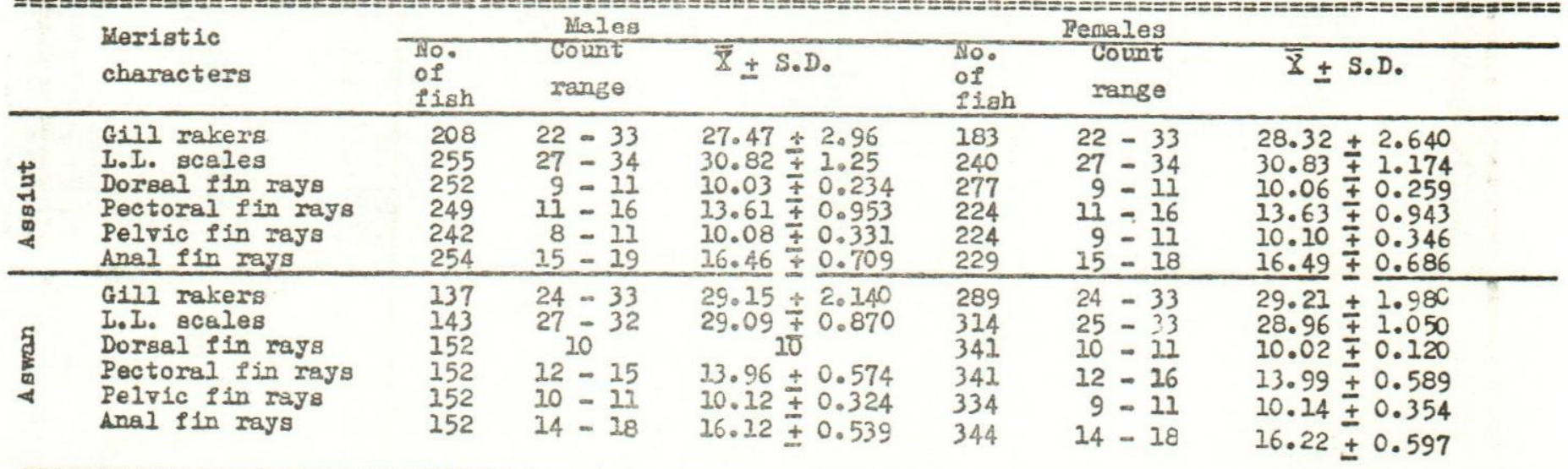



Table 3: The ranges and means of certain merlistic characters of A nurge (combined sexes) off Aasiut
and Aswan.

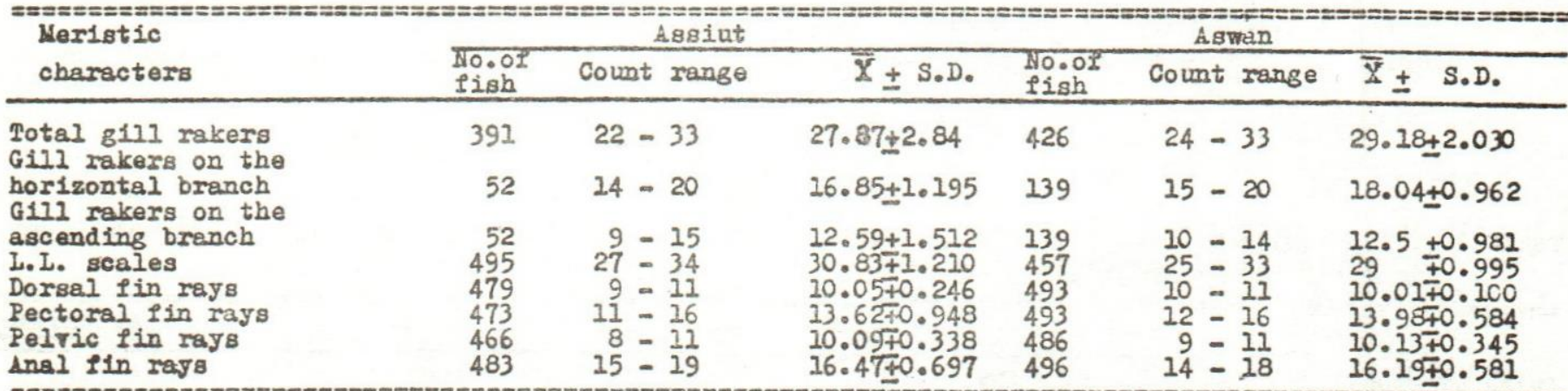

Table 4: The percentage of occurrence of the total gill raker counts on the firgt right side gill arch of A. nurse (males and females) off Assiut and Aswan.

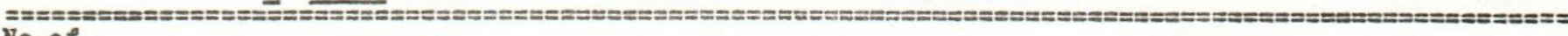
עo.01

Bill

rakerg Asgiut Aswan

\begin{tabular}{|c|c|c|c|c|c|c|c|c|c|}
\hline \multirow[t]{2}{*}{ rakers } & \multicolumn{2}{|c|}{ Maleg } & \multicolumn{2}{|c|}{ Pemales } & \multicolumn{2}{|l|}{ Malea } & \multicolumn{3}{|c|}{ Females } \\
\hline & No.01 Lish & $\%$ & To. of fish & $\%$ & INo. of 11sh & $\%$ & Ho.01 & Iish & $\%$ \\
\hline $\begin{array}{l}22 \\
23 \\
24 \\
25 \\
26 \\
27 \\
28 \\
29 \\
30 \\
31 \\
32 \\
33\end{array}$ & $\begin{array}{r}5 \\
25 \\
18 \\
23 \\
32 \\
15 \\
16 \\
19 \\
25 \\
20 \\
14 \\
6\end{array}$ & $\begin{array}{r}2.40 \\
7.21 \\
8.65 \\
11.06 \\
15.38 \\
7.21 \\
7.69 \\
9.13 \\
10.02 \\
9.62 \\
6.73 \\
2.88\end{array}$ & $\begin{array}{r}1 \\
6 \\
13 \\
12 \\
18 \\
15 \\
22 \\
25 \\
28 \\
23 \\
16 \\
4\end{array}$ & $\begin{array}{r}0.55 \\
3.28 \\
7.10 \\
6.56 \\
9.84 \\
8.19 \\
12.02 \\
13.66 \\
15.30 \\
12.57 \\
8.74 \\
2.19\end{array}$ & $\begin{array}{r}- \\
\overline{5} \\
5 \\
10 \\
8 \\
14 \\
27 \\
31 \\
21 \\
12 \\
4\end{array}$ & $\begin{array}{r}- \\
3.65 \\
3.65 \\
7.29 \\
5.84 \\
10.22 \\
19.71 \\
22.63 \\
15.33 \\
8.76 \\
2.92\end{array}$ & $\begin{array}{r}- \\
\overline{4} \\
8 \\
23 \\
22 \\
35 \\
53 \\
66 \\
39 \\
20 \\
9\end{array}$ & & $\begin{array}{c}- \\
- \\
1.38 \\
2.77 \\
7.96 \\
7.61 \\
12.11 \\
18.34 \\
22.84 \\
16.96 \\
6.92 \\
3.11\end{array}$ \\
\hline
\end{tabular}

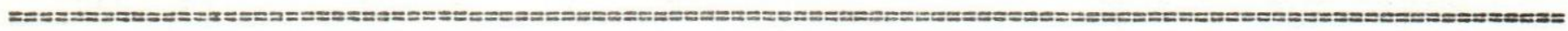


CERTAIN MERISTICS OF TWO NILE CHARCOID FISHES

Table 5i The perceatage of occurrence of the total gill raker counts on the first right side gill arch of A. nurge (combined sexss) off Assiut and Aswan.

\begin{tabular}{|c|c|c|c|c|}
\hline \multirow{2}{*}{$\begin{array}{l}\text { Irumber of } \\
\text { gill } \\
\text { rakers }\end{array}$} & \multicolumn{2}{|c|}{ Ass1ut } & \multicolumn{2}{|c|}{ Astran } \\
\hline & IJo. of fish & $\%$ & Ho. of fish & $\%$ \\
\hline 22 & 6 & 1.53 & - & - \\
\hline 23 & 21 & 5.37 & - & - \\
\hline 24 & 32 & 7.93 & 9 & 2.11 \\
\hline 25 & 35 & 8.95 & 13 & 3.05 \\
\hline 26 & 50 & 12.79 & 33 & 7.75 \\
\hline 27 & 30 & 7.67 & 30 & 7.04 \\
\hline 28 & 38 & 9.72 & 49 & 11.50 \\
\hline 29 & 44 & 11.25 & 80 & 18.78 \\
\hline 30 & 53 & 13.25 & 97 & 22.77 \\
\hline 31 & 43 & 11.00 & 70 & 16.43 \\
\hline 32 & 30 & $7 \cdot 67$ & 32 & 7.51 \\
\hline 33 & 10 & 2.56 & 13 & 3.05 \\
\hline
\end{tabular}

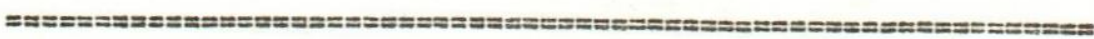

Table 6: Average number of gill rakers at $10 \mathrm{~mm}$ length group intervals of Assiut and Aswan combinad sex samples of A. nurge.

\begin{tabular}{|c|c|c|c|c|c|c|}
\hline \multirow{2}{*}{$\begin{array}{l}\text { Length } \\
\text { group } \\
\text { (mm) }\end{array}$} & \multicolumn{4}{|c|}{ AsBit } & \multicolumn{2}{|c|}{ Aswan } \\
\hline & $\begin{array}{l}\text { No.of } \\
\text { fish }\end{array}$ & $\begin{array}{l}\text { Average } \\
\text { number of } \\
\text { gill rakers }\end{array}$ & $\begin{array}{l}\text { Standard } \\
\text { deviation }\end{array}$ & $\begin{array}{l}\text { No.01 } \\
\text { floh }\end{array}$ & $\begin{array}{c}\text { Average } \\
\text { numbor of } \\
\text { gill rakers }\end{array}$ & $\begin{array}{r}\text { Standard } \\
\text { deviation } \\
\end{array}$ \\
\hline $\begin{array}{l}90 \\
100 \\
110 \\
120 \\
130 \\
140 \\
150 \\
160 \\
170 \\
180 \\
190 \\
200 \\
210 \\
220\end{array}$ & $\begin{array}{r}\overline{4} \\
11 \\
18 \\
43 \\
62 \\
81 \\
71 \\
40 \\
30 \\
15 \\
5 \\
6 \\
5\end{array}$ & $\begin{array}{l}23.72 \\
25.36 \\
24.67 \\
25.88 \\
27.84 \\
28.85 \\
28.90 \\
28.00 \\
28.30 \\
27.60 \\
29.00 \\
29.67 \\
29.00\end{array}$ & $\begin{array}{l}2.062 \\
2.0638 \\
1.029 \\
2.402 \\
2.776 \\
2.569 \\
2.641 \\
2.727 \\
2.437 \\
2.613 \\
2.121 \\
2.503 \\
2.000\end{array}$ & $\begin{array}{r}13 \\
29 \\
94 \\
170 \\
78 \\
30 \\
6 \\
3 \\
3 \\
= \\
= \\
= \\
=\end{array}$ & $\begin{array}{c}26.77 \\
28.45 \\
29.40 \\
29.30 \\
29.60 \\
28.67 \\
30.17 \\
28.00 \\
27.33 \\
= \\
= \\
= \\
=\end{array}$ & $\begin{array}{c}2.315 \\
2.114 \\
2.049 \\
1.817 \\
2.072 \\
2.123 \\
1.329 \\
1.732 \\
1.155 \\
= \\
= \\
= \\
=\end{array}$ \\
\hline
\end{tabular}


A. KHALIL, et $\underline{\text { al. }}$.

Table 7: Analysis of variance of total gill raker counts on the first right side $g 111$ axch of $A_{0}$ nurse off Assiut and Iswan to show the comelation between those counts and the flsh length.

\begin{tabular}{|c|c|c|}
\hline & Assiut & Aswan \\
\hline$s_{l}^{2}$ & 6.518 & 3.877 \\
\hline$s_{2}^{2}$ & 34.247 & 18.262 \\
\hline$F$ & 5.238 & $4 \cdot 710$ \\
\hline $\mathrm{d} \cdot \mathfrak{l}_{1}, \mathrm{~d} \cdot \mathfrak{f}_{2}$ & 378,11 & 417,7 \\
\hline
\end{tabular}

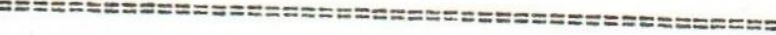

$\begin{aligned} s_{1}^{2}= & \text { Within-groups mean square. } \\ s_{2}^{2}= & \begin{array}{l}\text { Deviation from linearity mean } \\ \text { square. }\end{array}\end{aligned}$



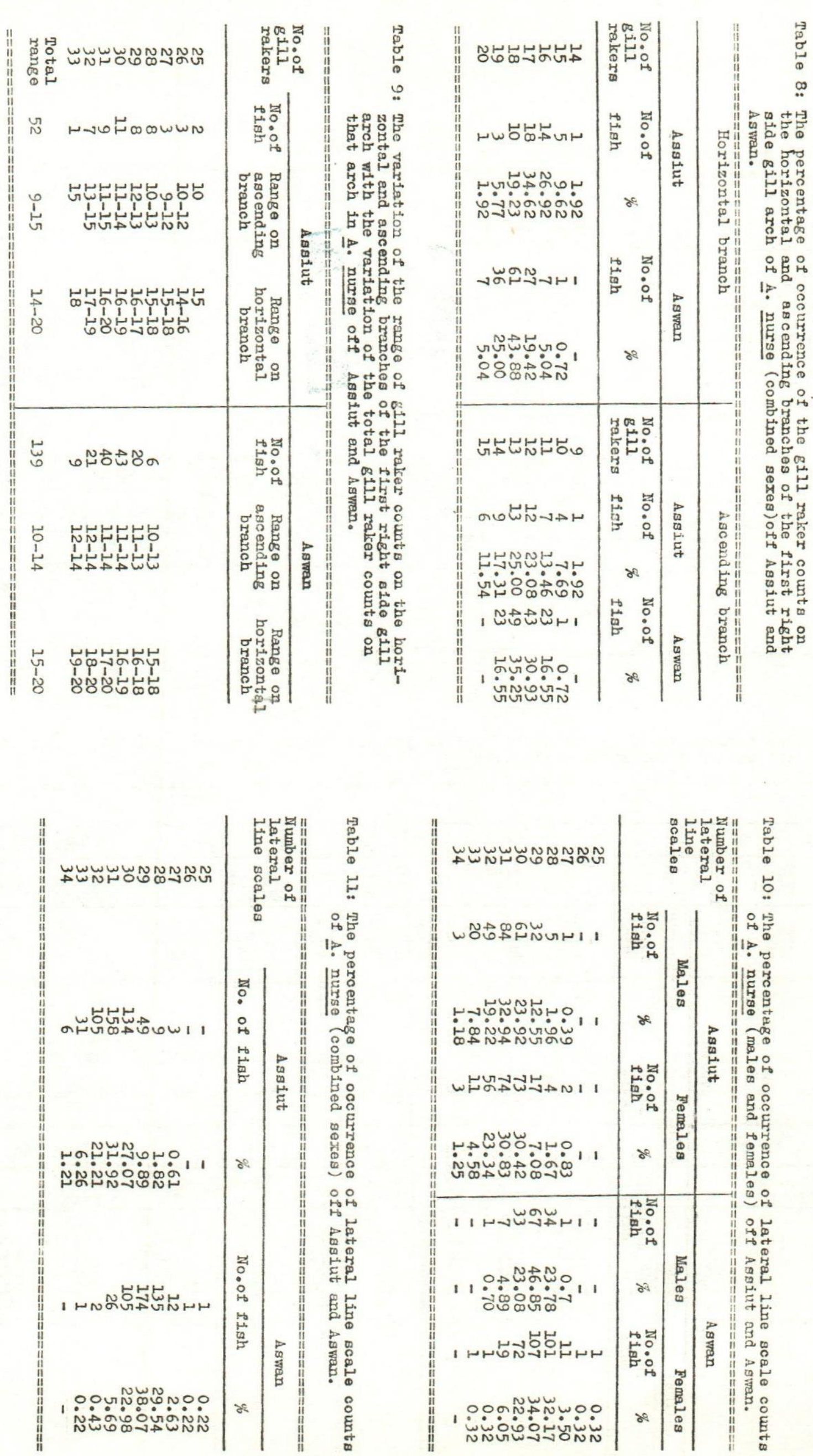
A. KHALIL, et $\underline{\text { al. }}$

Table 12: The ranges end means of certein meristic characters of combloed sex samples of A. nurge and A. beremose off Assiut.

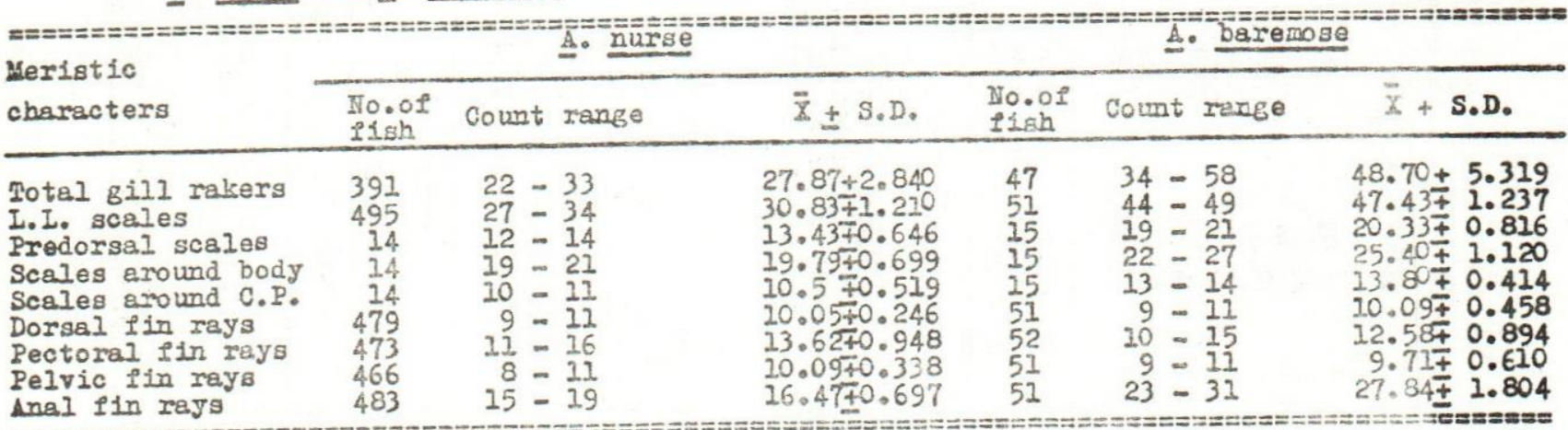

$16.47+0.697$

$27.84 \pm 1.804$

Table 13: The percentege of occurrence of counts of predorsal scales, scales around the body and ecsles around the caudel peduncle of de nurse (combined seres) off. Aasiut.

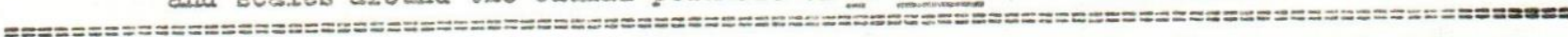
Predorsal scales Sceles around body

Scales around caudal pedunclo

\begin{tabular}{|c|c|c|c|c|c|c|c|c|}
\hline Counts & Ho.of fish & $\%$ & counts & Io.0 fish & $\%$ & counts & No.01 fish & $\%$ \\
\hline $\begin{array}{l}12 \\
13 \\
14\end{array}$ & $\begin{array}{l}\frac{1}{6} \\
7\end{array}$ & $\begin{array}{l}7.74 \\
42.86 \\
50\end{array}$ & $\begin{array}{l}19 \\
20 \\
21\end{array}$ & $\begin{array}{l}5 \\
7 \\
2\end{array}$ & $\begin{array}{l}35.71 \\
50 \\
14.29\end{array}$ & $\begin{array}{l}10 \\
11\end{array}$ & $\begin{array}{l}7 \\
7\end{array}$ & $\begin{array}{l}50 \\
50\end{array}$ \\
\hline
\end{tabular}

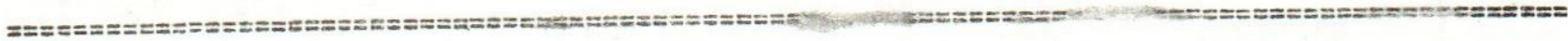

Table 14: The percentage of occurrence of dorsel fin ray counts of Assiut and Aswan mele, femele and combined sex samples of $\mathrm{A}$. nurse.

\begin{tabular}{|c|c|c|c|c|c|c|c|c|c|c|c|c|}
\hline \multirow{3}{*}{$\begin{array}{l}\text { Pin ray } \\
\text { counts }\end{array}$} & \multicolumn{6}{|c|}{ Assiut } & \multicolumn{6}{|c|}{ Aswan } \\
\hline & \multicolumn{2}{|c|}{ or } & \multicolumn{2}{|c|}{$q$} & \multicolumn{2}{|c|}{ Combined } & \multicolumn{2}{|c|}{$0^{T}$} & \multicolumn{2}{|c|}{$q$} & \multicolumn{2}{|c|}{ Combined } \\
\hline & $\begin{array}{l}\text { No.or } \\
\text { sish }\end{array}$ & 当 & $\begin{array}{l}\text { INo.of } \\
\text { Ilah }\end{array}$ & $\%$ & $\begin{array}{l}\text { Ijo. of } \\
\text { sish }\end{array}$ & $\%$ & $\begin{array}{l}270.01 \\
21 \text { sh }\end{array}$ & $\%$ & $\begin{array}{l}\text { N10.01 } \\
\text { Ligh }\end{array}$ & $\%$ & $\begin{array}{l}\text { No.0 } \\
\text { Iish }\end{array}$ & $\%$ \\
\hline $\begin{array}{l}99 \\
11\end{array}$ & $\begin{array}{r}33 \\
238 \\
11\end{array}$ & $\begin{array}{r}1.19 \\
94.44 \\
4.37\end{array}$ & $27 \frac{1}{15}$ & $\begin{array}{r}0.44 \\
92.95 \\
6.61\end{array}$ & $\begin{array}{r}4 \\
449 \\
26\end{array}$ & $\begin{array}{r}0.83 \\
93.74 \\
5.43\end{array}$ & 252 & 100 & 336 & $\begin{array}{r}98.53 \\
1.47\end{array}$ & $4 \overline{88}$ & $\begin{array}{r}98.9 \\
1.0\end{array}$ \\
\hline
\end{tabular}

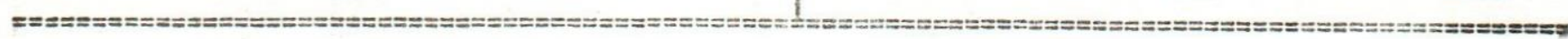

Table 15: The percentage of occurrence of pectoral ill ray countr of hasiut and Aswan male, female and combined sex samples of A. nurge.

\begin{tabular}{|c|c|c|c|c|c|c|c|c|c|c|c|c|}
\hline \multirow{3}{*}{$\begin{array}{l}\text { Pin ray } \\
\text { counts }\end{array}$} & \multicolumn{6}{|c|}{ Assiut } & \multicolumn{6}{|c|}{ Aswan } \\
\hline & \multicolumn{2}{|c|}{$\sigma^{7}$} & \multicolumn{2}{|c|}{ q } & \multicolumn{2}{|c|}{ Combined } & \multicolumn{2}{|c|}{$\sigma^{x}$} & \multicolumn{2}{|c|}{$q$} & \multicolumn{2}{|c|}{ Combined } \\
\hline & $\begin{array}{l}\text { Ho.01 } \\
\text { fish }\end{array}$ & $\%$ & $\begin{array}{l}\text { To.of } \\
\text { fish }\end{array}$ & \% & $\begin{array}{l}\text { Ho. of } \\
\text { Iish }\end{array}$ & $\%$ & $\begin{array}{l}\text { No. of } \\
\text { fiels }\end{array}$ & $\%$ & $\begin{array}{l}\text { No.01 } \\
\text { 1iah }\end{array}$ & $\%$ & $\begin{array}{l}\text { No.01 } \\
11 \mathrm{gh}\end{array}$ & $\%$ \\
\hline $\begin{array}{l}11 \\
12 \\
13 \\
14 \\
15 \\
16\end{array}$ & $\begin{array}{r}4 \\
30 \\
65 \\
113 \\
35 \\
2\end{array}$ & $\begin{array}{r}1.61 \\
12.05 \\
26.10 \\
45.38 \\
14.06 \\
0.80\end{array}$ & $\begin{array}{r}4 \\
24 \\
59 \\
104 \\
31 \\
2\end{array}$ & $\begin{array}{r}1.79 \\
10.71 \\
26.34 \\
46.43 \\
13.84 \\
0.88\end{array}$ & $\begin{array}{r}8 \\
54 \\
124 \\
217 \\
66 \\
4\end{array}$ & $\begin{array}{r}1.69 \\
11.42 \\
26.22 \\
45.88 \\
13.95 \\
0.84\end{array}$ & $\begin{array}{r}7 \\
25 \\
105 \\
21 \\
=\end{array}$ & $\begin{array}{r}0.66 \\
16.45 \\
69.07 \\
13.82 \\
=\end{array}$ & $\begin{array}{r}3 \\
51 \\
235 \\
51 \\
1\end{array}$ & $\begin{array}{r}- \\
0.88 \\
14.96 \\
68.91 \\
14.96 \\
0.29\end{array}$ & $\begin{array}{r}4 \\
76 \\
340 \\
72 \\
1\end{array}$ & $\begin{array}{r}0 . \\
0.81 \\
15.42 \\
68.97 \\
14.60 \\
0.20\end{array}$ \\
\hline
\end{tabular}


CERTAIN MERISTICS OF TWO NILE CHARCOID FISHES

Table 16: The percentege of occurrence of pelvic fin ray counts of Asglut and Aswan male, female and combined sex samples of A. nurse.

\begin{tabular}{|c|c|c|c|c|c|c|c|c|c|c|c|c|}
\hline \multirow{3}{*}{$\begin{array}{l}\text { Pin } \\
\text { rey } \\
\text { counts }\end{array}$} & \multicolumn{6}{|c|}{ Asaiut } & \multicolumn{6}{|c|}{ Aswan } \\
\hline & \multicolumn{2}{|c|}{$\sigma^{7}$} & \multicolumn{2}{|c|}{ 우 } & \multicolumn{2}{|c|}{ Combined. } & \multicolumn{2}{|c|}{$\sigma^{x}$} & \multicolumn{2}{|c|}{ 우 } & \multicolumn{2}{|c|}{ Combined } \\
\hline & $\begin{array}{l}\text { No.of } \\
\text { fish }\end{array}$ & $\%$ & $\begin{array}{l}\text { Ho.op } \\
\text { fiah }\end{array}$ & $\%$ & $\begin{array}{l}\text { INo.01 } \\
\text { fish }\end{array}$ & $\%$ & $\begin{array}{l}\text { \#o.of } \\
\text { fish }\end{array}$ & $\%$ & $\begin{array}{l}\text { Ho.or } \\
\text { I1sh }\end{array}$ & $\%$ & $\begin{array}{l}\text { Bo.os } \\
\text { fish }\end{array}$ & $\%$ \\
\hline $\begin{array}{r}8 \\
9 \\
10 \\
11\end{array}$ & $\begin{array}{r}1 \\
217 \\
23\end{array}$ & $\begin{array}{r}0.41 \\
0.41 \\
89.67 \\
9.51\end{array}$ & $\begin{array}{r}53 \\
195 \\
26\end{array}$ & $\begin{array}{r}- \\
87.34 \\
11.05 \\
11.61\end{array}$ & $\begin{array}{r}1 \\
4 \\
412 \\
49\end{array}$ & $\begin{array}{r}0.21 \\
0.86 \\
88.41 \\
10.52\end{array}$ & $\begin{array}{r}- \\
134 \\
18\end{array}$ & $\begin{array}{c}-5.16 \\
11.84\end{array}$ & $\begin{array}{r}\overline{1} \\
286 \\
47\end{array}$ & $\begin{array}{c}0.3 \\
85.63 \\
14.07\end{array}$ & $\begin{array}{r}\overline{1} \\
65\end{array}$ & $\begin{array}{r}0.21 \\
86.42 \\
13.37\end{array}$ \\
\hline
\end{tabular}

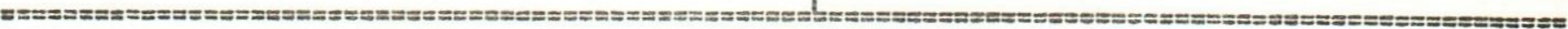

Table 17: The percentage of occurrence of anal in ray counts of Assiut and Aswan male, female and combined sex samples of d. nurse.

\begin{tabular}{|c|c|c|c|c|c|c|c|c|c|c|c|c|}
\hline \multirow{3}{*}{$\begin{array}{l}\text { Fin } \\
\text { rey } \\
\text { counts }\end{array}$} & \multicolumn{6}{|c|}{ Assiut } & \multicolumn{6}{|c|}{ Aswan } \\
\hline & \multicolumn{2}{|c|}{$\sigma^{x}$} & \multicolumn{2}{|r|}{ 오 } & \multicolumn{2}{|c|}{ Combined } & \multicolumn{2}{|c|}{$\sigma^{7}$} & \multicolumn{2}{|c|}{9} & \multicolumn{2}{|c|}{ Combined } \\
\hline & $\begin{array}{l}\text { No.of } \\
\text { I ish }\end{array}$ & $\bar{\omega}$ & $\begin{array}{l}\text { No. of } \\
\text { I igh }\end{array}$ & $\%$ & $\begin{array}{l}\text { No. of } \\
\text { fish }\end{array}$ & $\%$ & $\begin{array}{l}\text { No.of } \\
\text { I Ish }\end{array}$ & $\%$ & $\begin{array}{l}\text { Io.01 } \\
\text { I Igh }\end{array}$ & $\%$ & $\begin{array}{l}\text { Wo.01 } \\
\text { fish }\end{array}$ & $\%$ \\
\hline $\begin{array}{l}14 \\
15 \\
16 \\
17 \\
18 \\
19\end{array}$ & $\begin{array}{r}13 \\
130 \\
94 \\
16 \\
1\end{array}$ & $\begin{array}{r}5.12 \\
51.18 \\
37.01 \\
6.30 \\
0.39\end{array}$ & $\begin{array}{r}59 \\
125 \\
89 \\
26 \\
-\end{array}$ & $\begin{array}{c}3.93 \\
50.22 \\
38.86 \\
6.99 \\
=\end{array}$ & $\begin{array}{r}22 \\
245 \\
183 \\
32 \\
1\end{array}$ & $\begin{array}{r}4.55 \\
50.72 \\
37.89 \\
6.63 \\
0.21\end{array}$ & $\begin{array}{r}7 \\
9 \\
115 \\
25 \\
2 \\
-\end{array}$ & $\begin{array}{c}0.66 \\
5.92 \\
75.66 \\
16.45 \\
1.31 \\
-\end{array}$ & $\begin{array}{r}3 \\
12 \\
248 \\
70 \\
11 \\
-\end{array}$ & $\begin{array}{c}0.87 \\
3.49 \\
72.09 \\
20.35 \\
3.20 \\
-\end{array}$ & $\begin{array}{r}4 \\
21 \\
363 \\
95 \\
13 \\
-\end{array}$ & $\begin{array}{r}0.81 \\
4.23 \\
73.19 \\
19.15 \\
2.62 \\
-\end{array}$ \\
\hline
\end{tabular}

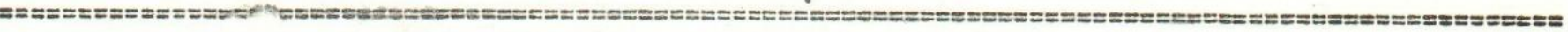

Table 18 : The percentege os evcurrence of lateral line scele counts of A. baremoge of Assiut.

\begin{tabular}{|c|c|c|c|c|c|c|c|}
\hline $\begin{array}{l}\text { Number of laterel } \\
\text { line scales }\end{array}$ & 44 & 45 & 46 & 47 & 48 & 49 & Total \\
\hline $\begin{array}{l}\text { Number of siah } \\
\text { examined }\end{array}$ & 1 & 4 & 5 & 12 & 20 & 9 & 51 \\
\hline$\%$ & 1.96 & 7.84 & 9.8 & 23.5 & 39.2 & 17. & \\
\hline
\end{tabular}

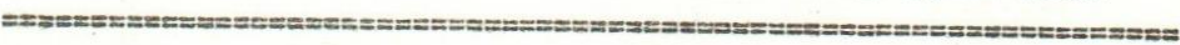

Table 19: The percentage of occurrence of cornts of predorsel scales, scales around the body and scales around caudal pedunclo of A. baremose of Assiut.

\begin{tabular}{|c|c|c|c|c|c|c|c|c|}
\hline \multicolumn{3}{|c|}{ Predorsal scales } & \multirow{2}{*}{ Sceles } & \multirow{2}{*}{$\begin{array}{l}\text { around } \\
\text { body } \\
\begin{array}{l}\text { No.01 } \\
\text { I1ah }\end{array}\end{array}$} & \multirow{2}{*}{$\frac{t h e}{\%}$} & \multicolumn{3}{|c|}{$\begin{array}{l}\text { Scales around } \\
\text { caudal peduncle }\end{array}$} \\
\hline Counte & $\begin{array}{l}\text { To. of } \\
\text { Iiah }\end{array}$ & $\%$ & & & & Counts & $\begin{array}{l}\text { Ho. of } \\
\text { Iigh }\end{array}$ & $\%$ \\
\hline 19 & 3 & 20 & 22 & 1 & 6.67 & 13 & 3 & 20 \\
\hline 20 & 4 & 26.67 & 25 & 6 & 40 & 14 & 12 & 80 \\
\hline 21 & 8 & 53.33 & 26 & 7 & 46.66 & & & \\
\hline & & & 27 & 1 & 6.67 & & & \\
\hline
\end{tabular}




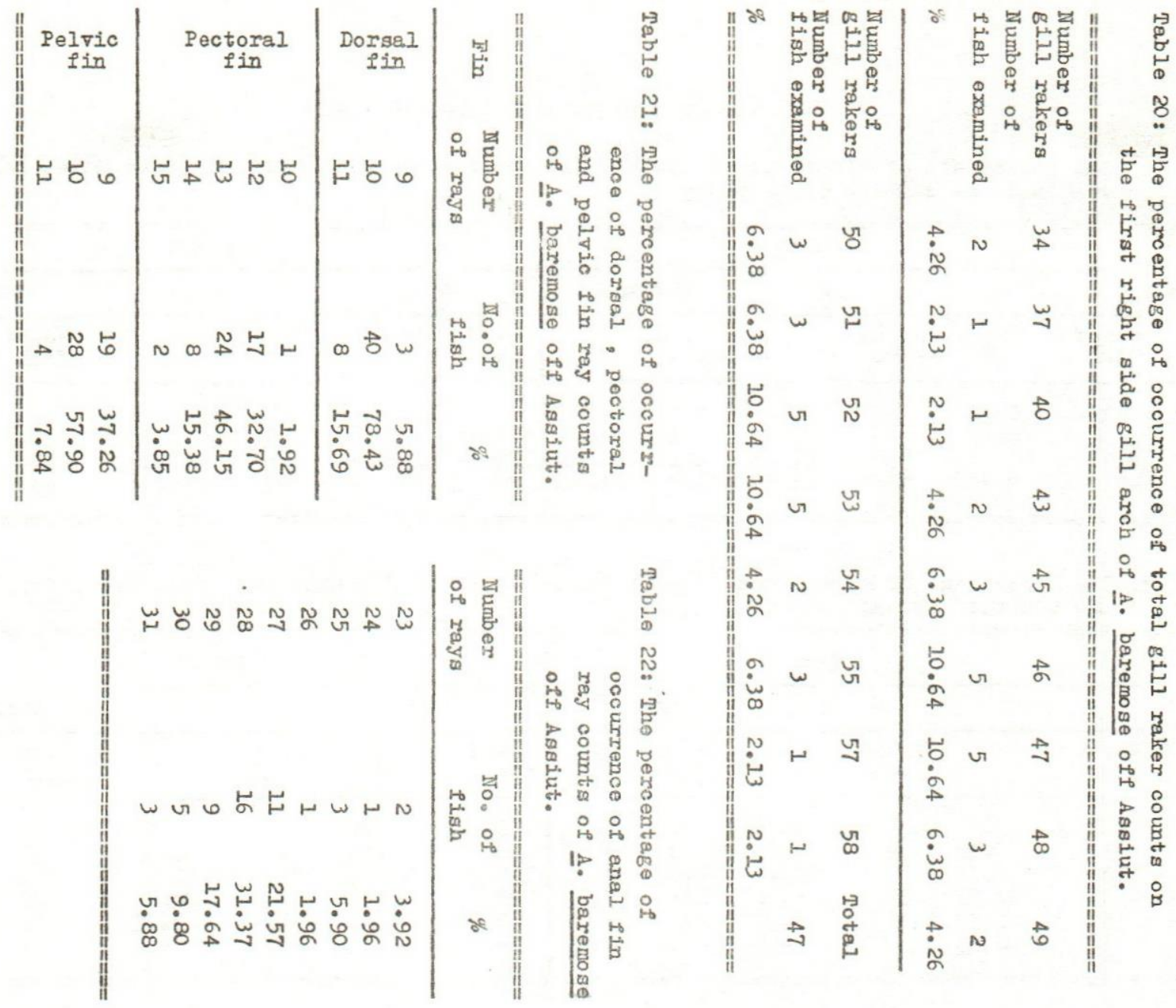

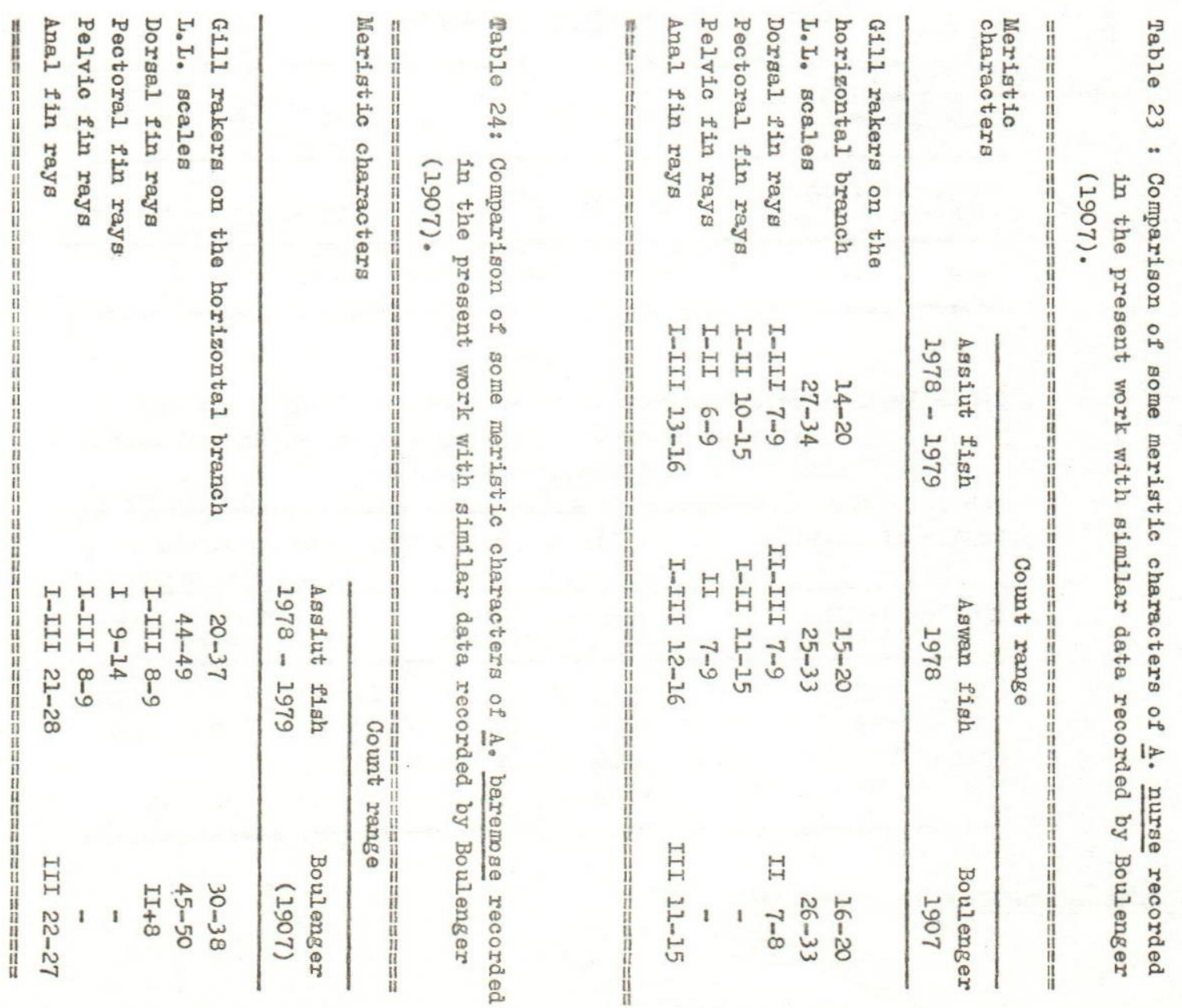

